Article

Global Development and Regional

Economic Situation: Issues, Challenges

and Remedies
Journal of Development Economics and

Management Research Studies (JDMS)

01(01), 1-12, July-September 2019

@ Center for Development Economic Studies (CDES)

Reprints and permissions

http://www.cdes.org.in/

http://www.cdes.org.in/journal/

Dr.S.Thirunavukkarasu ${ }^{1}$ and T.Lakshmi Pradha ${ }^{2}$

\title{
ABSTRACT
}

The world economies are with slow economic growth and lesser world gross product than what is expected due to deteriorating growth in international trade. In addition, reduced global investment, unemployment, low wage growth, inflation, bank failures, mounting debts, low commodity prices, escalating global oil prices, geopolitical tensions are the factors that have hindered the growth of world economies. Armed conflict, terrorism, geopolitical tension and political instability are the serious factors that tremble world peace, global development and regional economic disparity. This article throw insights into the issues, challenges and strategies in global development on population, international trade and development, global investment, inclusive growth, employment, finance, gender issues, food security, internet and communication industry.

Key words: Global, regional, development, international trade, food security, population, financial.

Economic development of a country is generally understood as the economic activities carried out within that country and with other countries which aids in its overall development. This topic has drawn too much attention in this decade and has been a noteworthy point in all the political speeches. But in reality does these matches with the facts. Balanced global development is not achieved due to weak growth in international trade and subdued global investment in many countries. The world economy has been trapped with slow economic growth. The world gross product (WGP) is not expanding as expected which is caused by dwindling growth in international trade. This global economic situation is an onslaught of the great recession and it curtailed the growth of many countries. The weak performance of countries has brought sluggishness to the world economy and also brought downswing in the growth of productivity in many countries. Reduced global investment, unemployment, low wage growth, inflation, bank failures, mounting debts, low commodity prices, escalating global oil prices, geopolitical tensions etc., are the factors to be addressed commonly by the countries of the world to retain their economic development situation.

\footnotetext{
${ }^{1}$ Former Principal and HOD of Economics, Ramakrishna Mission Vivekananda College (Autonomous), Chennai \& President, Center for Development Economics Studies (CDES), Chennai @ cdes.org.in.

${ }^{2}$ Research Scholar, Institute of Distance Education, University of Madras, Chennai-600 005.
} 
In addition, the new economic policy of the countries has brought tremendous changes on social, economic, business, cultural, psychological, agricultural, ecological, and technological front. The achievement of these countries and their share in the international trade is a matter of concern and also debatable. Globalization, industrialization, urbanization, transfer of technology, level of employment and income in the countries have created not only momentum in the economic situation but also resulted in environmental issues. Therefore, now, it is the duty of the decision makers, scientists and academicians to evolve and recommend suitable strategy and technology to sustain the cadence of development. Sustainable development is a tool to realize and protect environment and also to achieve economic development particularly in developing countries that grapples with ever increasing problems.

According to António Guterres, UN Secretary-General that "As the World Economic Situation and Prospects 2018 demonstrates, current macroeconomic conditions offer policymakers greater scope to address some of the deep-rooted systemic issues and short-term thinking that continue to hamper progress towards the Sustainable Development Goals." The global economic growth in 2016 was 2.4 percent and it is much below the achievements during 2011. The global growth is anticipated steady growth at 3 percent during 2018-2019. The robust global demand has accelerated the Gross Fixed Capital Formation to 60 percent in the global economic activity (United Nations, 2018).

This article attempts to study the issues, challenges and strategies in global development on population, international trade and development, global investment, inclusive growth, employment, finance, gender issues, food security, internet and communication industry.

The first key factor for achieving economic development is population and resources. The population explosion and poor availability of resources in the low income countries hinder the growth and push them vulnerable to famine, to malnutrition, and to poverty (Theodore W.Schultz, 1978). Population growth also breeds poverty and environmental issues to a country. The ageing of people also influences the economic situation of country. Therefore, the countries of the world have to seriously attend to these issues to solve many upcoming problems that they will be facing in the near future. The following chart provides the population projection in 2100. The projected rate gives us a strong warning signal which needs a very careful attention and planning to face them in the days to come. 


\section{World Population}

Projected world population until 2100

1990 hing 5.3

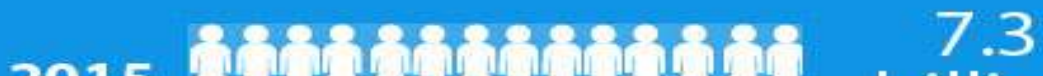

2015 utintulitivition

2030 fillion

2050 fillion

2100 illion

Source: United Nations Department of Economic and Social Affairs,

Population Division, Worla Population Prospects: The 2015 Revision

Produced by: United Nations Department of Public Information

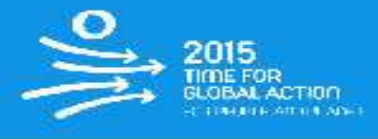

Secondly, international trade and development are interwoven factors in the global economic situation. The international trade defines the export potential of a country and it is not evenly available to the different countries. Table 1 and Chart 2 showcases the dollar value of exports of the world, developed and developing countries. The chart clearly points that the dollar value of exports of the world was -19.6 percent in 2009 which has increased to 6.4 percent in 2019 with a highest of 19.3 percent in 2010 and lowest in -0.1 percent in 2016 . The position is better for countries of Economies in transition (-32.3 percent in 2009 and 6.9 percent in 2019), Commonwealth of independent States and Georgia (-32.6 percent in 2009 and 6.9 percent in 2019), Developed Asia and Pacific countries (-23.1 percent in 2009 and 6.5 percent in 2019) etc. 


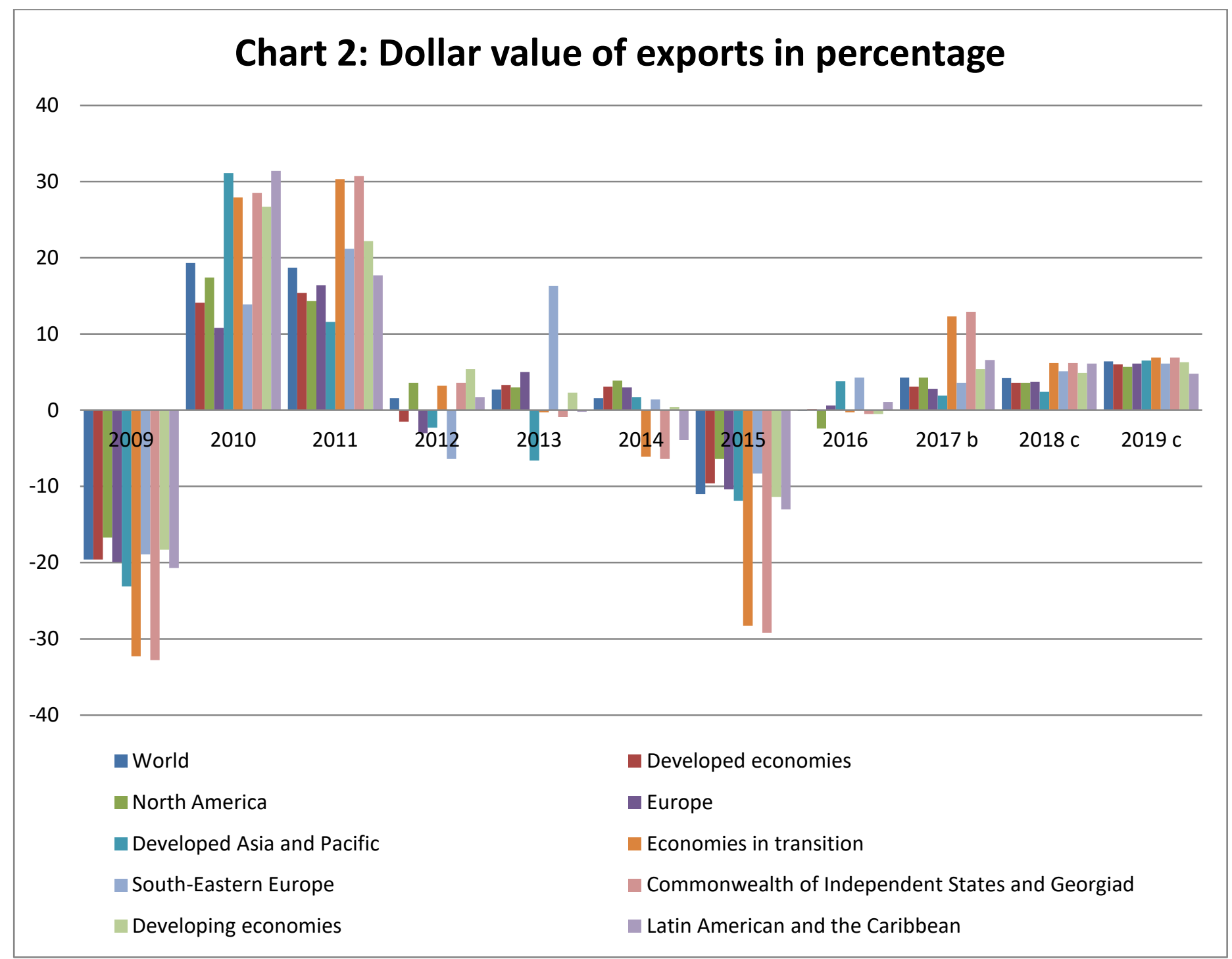

Chart 3 provides the details of dollar value of imports by the countries under major categorization. Table 1 portrays that the value of imports of the World was -10.7 percent and 3.7 percent in 2019 with a highest of 13 percent in 2010. The performance of South Asian countries (1.3 percent in 2009 and 7.6 percent in 2019) is better than East Asian countries (-6.1 percent in 2009 and 3.7 percent in 2019), West Asian countries (-10.0 percent in 2009 and 2.5 percent in 2019) etc., as shown in the chart. 


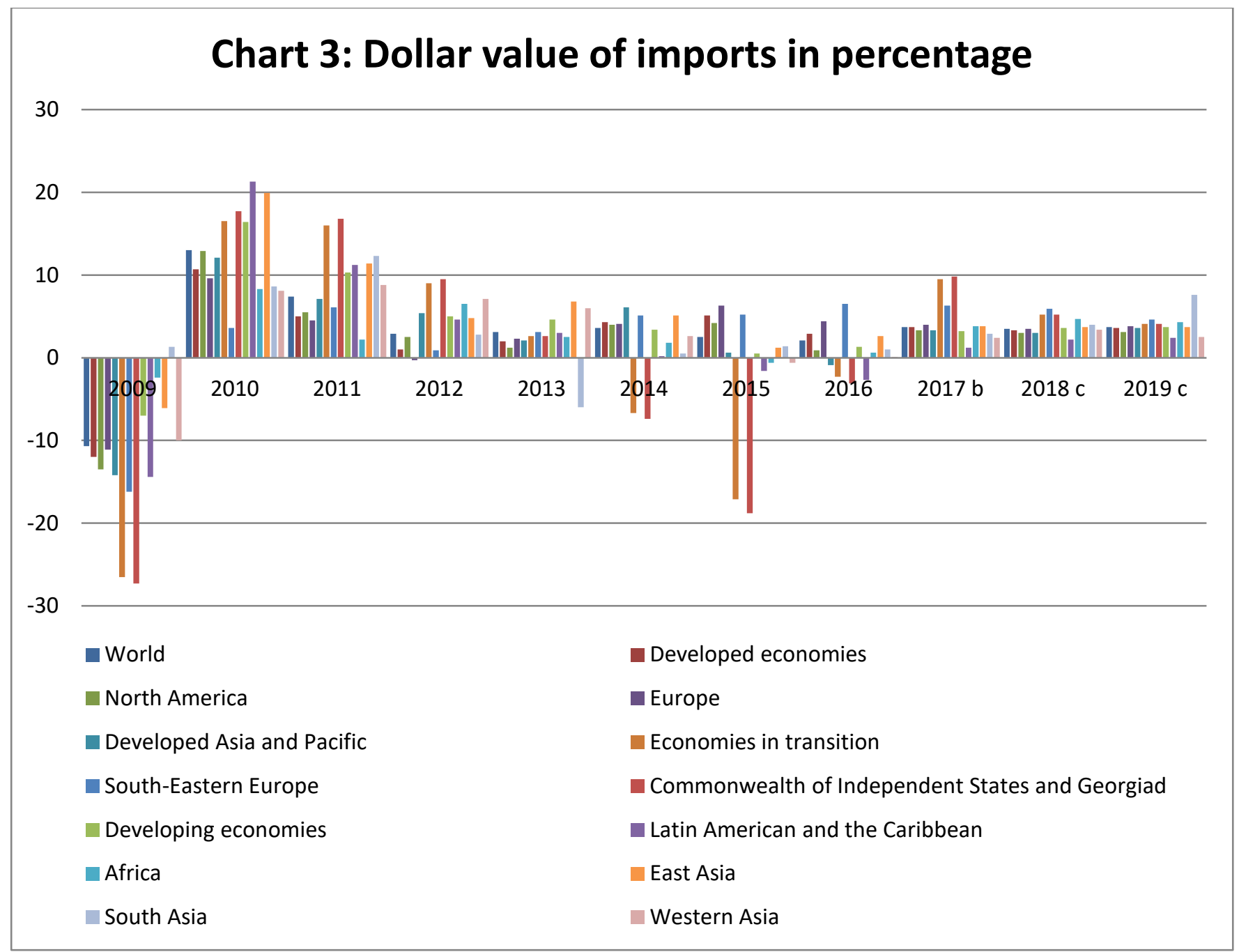

Chart 4 provides the exports and imports of the World from 2009 to 2019 and it indicates decrease in gap in the growth from 2009 to 2019. And it is a good indicator of improving world trade. Once the gap reduces the foreign reserve position of those countries will improve and they can tide over all their BOP issues. 


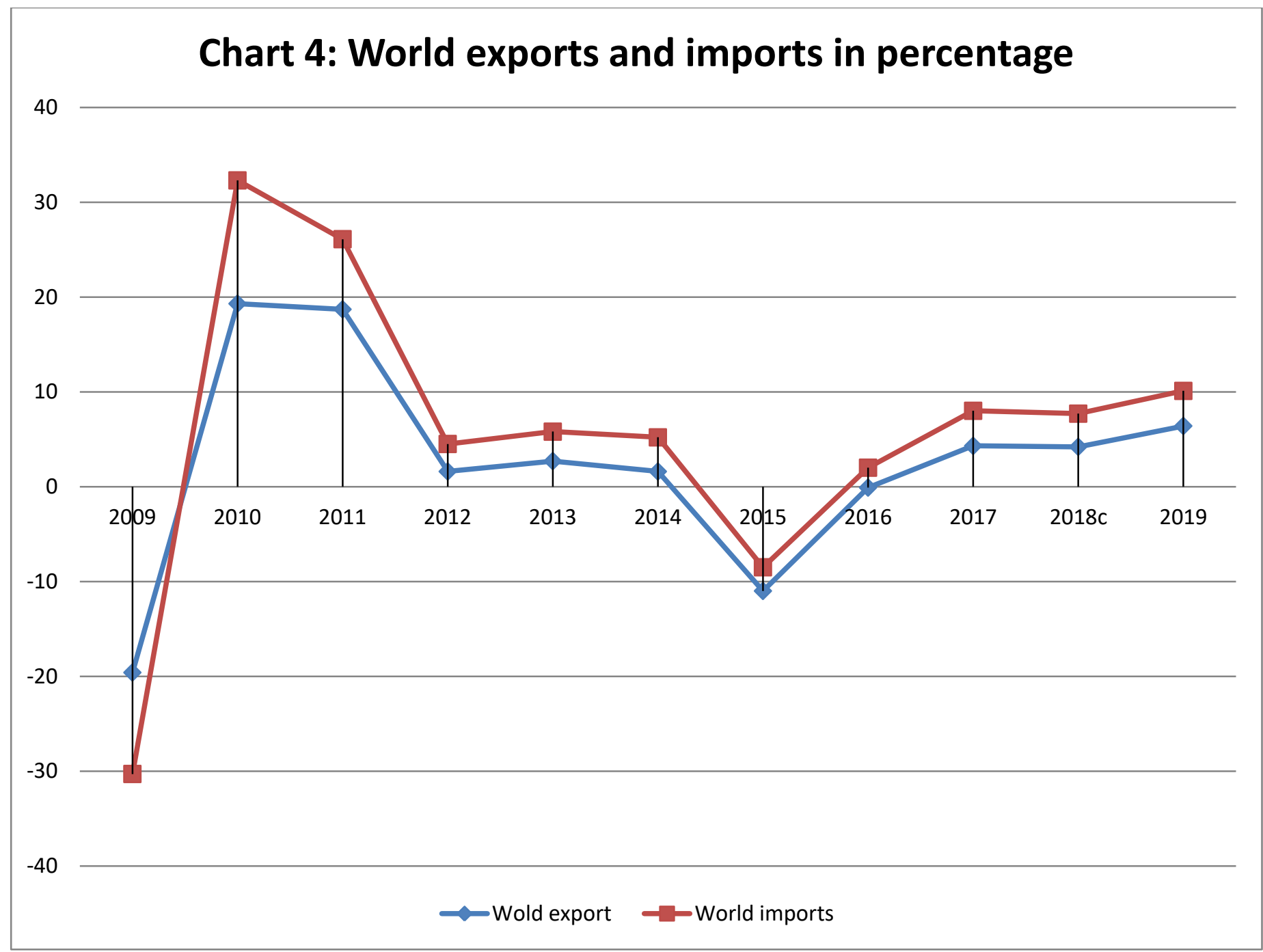

Table 1: World trade: ${ }^{\text {a }}$ Changes in value and volume of exports and imports by major country group, 2009-2019 (in Annual percentage change)

\begin{tabular}{|c|c|c|c|c|c|c|c|c|c|c|c|}
\hline & 2009 & 2010 & 2011 & 2012 & 2013 & 2014 & 2015 & 2016 & $\begin{array}{c}2017 \\
b\end{array}$ & $\underset{c}{2018}$ & $\underset{c}{2019}$ \\
\hline \multicolumn{12}{|c|}{ DOLLAR VALUE OF EXPORTS } \\
\hline World & -19.6 & 19.3 & 18.7 & 1.6 & 2.7 & 1.6 & -11.0 & -0.1 & 4.3 & 4.2 & 6.4 \\
\hline $\begin{array}{l}\text { Developed } \\
\text { economies }\end{array}$ & -19.6 & 14.1 & 15.4 & -1.5 & 3.3 & 3.1 & -9.6 & 0.1 & 3.1 & 3.6 & 6.0 \\
\hline North America & -16.7 & 17.4 & 14.3 & 3.6 & 3.0 & 3.9 & -6.4 & -2.4 & 4.3 & 3.6 & 5.7 \\
\hline Europe & -19.9 & 10.8 & 16.4 & -3.0 & 5.0 & 3.0 & -10.4 & 0.6 & 2.8 & 3.7 & 6.1 \\
\hline $\begin{array}{l}\text { Developed Asia and } \\
\text { Pacific }\end{array}$ & -23.1 & 31.1 & 11.6 & -2.3 & -6.6 & 1.7 & -11.9 & 3.8 & 1.9 & 2.4 & 6.5 \\
\hline Economies in & -32.3 & 27.9 & 30.3 & 3.2 & -0.3 & -6.1 & -28.3 & -0.3 & 12.3 & 6.2 & 6.9 \\
\hline
\end{tabular}




\begin{tabular}{|c|c|c|c|c|c|c|c|c|c|c|c|}
\hline tran & & & & & & & & & & & \\
\hline $\begin{array}{l}\text { South-Eastern } \\
\text { Europe }\end{array}$ & -18.9 & 13.9 & 21.2 & -6.4 & 16.3 & 1.4 & -8.3 & 4.3 & 3.6 & 5.1 & 6.1 \\
\hline $\begin{array}{l}\text { Commonwealth of } \\
\text { Independent States } \\
\text { and Georgia }\end{array}$ & -32.8 & 28.5 & 30.7 & 3.6 & -0.9 & -6.4 & -29.2 & -0.5 & 12.9 & 6.2 & 6.9 \\
\hline $\begin{array}{l}\text { Developing } \\
\text { economies }\end{array}$ & -18.3 & 26.7 & 22.2 & 5.4 & 2.3 & 0.4 & -11.4 & -0.5 & 5.4 & 4.9 & 6.3 \\
\hline $\begin{array}{l}\text { Latin American and } \\
\text { the Caribbean }\end{array}$ & -20.7 & 31.4 & 17.7 & 1.7 & -0.2 & -3.9 & -13.0 & 1.1 & 6.6 & 6.1 & 4.8 \\
\hline Africa & -26.5 & 28.2 & 16.2 & 9.0 & $10 . \overline{7}$ & -5.0 & -24.8 & -2.0 & 9.1 & 6.1 & 7.8 \\
\hline East Asia & -15.4 & 27.2 & 20.5 & 5.1 & 5.0 & 3.3 & -6.6 & -0.3 & 3.8 & 4.2 & 6.2 \\
\hline South Asia & -6.1 & 26.0 & 23.9 & -0.7 & 4.7 & -3.6 & -7.5 & 3.0 & 7.8 & 6.1 & 6.2 \\
\hline Western Asia & -25.9 & 20.0 & 36.1 & 11.1 & 0.6 & -2.4 & -23.8 & -4.0 & 8.8 & 6.4 & 7.8 \\
\hline VOLUME OF IMPO & & & & & & & & & & & \\
\hline World & -10.7 & 13.0 & 7.4 & 2.9 & 3.1 & 3.6 & 2.5 & 2.1 & 3.7 & 3.5 & 3.7 \\
\hline $\begin{array}{l}\text { Developed } \\
\text { economies }\end{array}$ & -12.0 & 10.7 & 5.0 & 1.0 & 2.0 & 4.3 & 5.1 & 2.9 & 3.7 & 3.3 & 3.6 \\
\hline North America & -13.5 & 12.9 & 5.5 & 2.5 & 1.2 & 4.0 & 4.2 & 0.9 & 3.3 & 3.0 & 3.1 \\
\hline Europe & -11.1 & 9.6 & 4.5 & -0.3 & 2.3 & 4.1 & 6.3 & 4.4 & 4.0 & 3.5 & 3.8 \\
\hline $\begin{array}{l}\text { Developed Asia and } \\
\text { Pacific }\end{array}$ & -14.2 & 12.1 & 7.1 & 5.4 & 2.1 & 6.1 & 0.6 & -0.9 & 3.3 & 3.0 & 3.6 \\
\hline $\begin{array}{l}\text { Economies in } \\
\text { transition }\end{array}$ & -26.5 & 16.5 & 16.0 & 9.0 & 2.6 & -6.7 & -17.1 & -2.3 & 9.5 & 5.2 & 4.1 \\
\hline $\begin{array}{l}\text { South-Eastern } \\
\text { Europe }\end{array}$ & -16.2 & 3.6 & 6.1 & 0.9 & 3.1 & 5.1 & 5.2 & 6.5 & 6.3 & 5.9 & 4.6 \\
\hline $\begin{array}{l}\text { Commonwealth of } \\
\text { Independent States } \\
\text { and Georgia }\end{array}$ & -27.3 & 17.7 & 16.8 & 9.5 & 2.6 & -7.4 & -18.8 & -3.1 & 9.8 & 5.2 & 4.1 \\
\hline $\begin{array}{l}\text { Developing } \\
\text { economies } \\
\end{array}$ & -7.0 & 16.4 & 10.3 & 5.0 & 4.6 & 3.4 & 0.5 & 1.3 & 3.2 & 3.6 & 3.7 \\
\hline $\begin{array}{l}\text { Latin American and } \\
\text { the Caribbean }\end{array}$ & -14.4 & 21.3 & 11.2 & 4.6 & 3.0 & 0.2 & -1.6 & -2.7 & 1.2 & 2.2 & 2.4 \\
\hline Africa & -2.4 & 8.3 & 2.2 & 6.5 & 2.5 & 1.8 & -0.6 & 0.6 & 3.8 & 4.7 & 4.3 \\
\hline East Asia & -6.1 & 19.9 & 11.4 & 4.8 & 6.8 & 5.1 & 1.2 & 2.6 & 3.8 & 3.7 & 3.7 \\
\hline South Asia & 1.3 & 8.6 & 12.3 & 2.8 & -6.0 & 0.5 & 1.4 & 1.0 & 2.9 & 4.0 & 7.6 \\
\hline Western Asia & -10.0 & 8.1 & 8.8 & 7.1 & 6.0 & 2.6 & -0.6 & 0.1 & 2.4 & 3.4 & 2.5 \\
\hline
\end{tabular}

Source: UN/DESA

a Includes goods and non-factor services.

b Partly estimated. 
c Baseline forecast, based in part on Project LINK.

d Georgia officially left the Commonwealth of Independent States on 18 August 2009. However, its performance is discussed in the context of this group of countries for reasons of geographic proximity and similarities in economic structure.

Table 2: Balance of payments on current accounts, by country or country group, summary table, 2008-2016 (in Billions of dollars).

\begin{tabular}{|c|c|c|c|c|c|c|c|c|c|}
\hline & 2008 & 2009 & 2010 & 2011 & 2012 & 2013 & 2014 & 2015 & 2016 \\
\hline Developed economies & -765.7 & -256.1 & -181.6 & -219.1 & -167.2 & 16.7 & -1.1 & 54.2 & 97.8 \\
\hline Japan & 142.6 & 145.3 & 221.0 & 129.8 & 59.7 & 45.9 & 36.8 & 134.1 & 188.1 \\
\hline United States & -681.4 & -372.5 & -430.7 & -444.6 & -426.2 & -349.5 & -373.8 & -434.6 & -451.7 \\
\hline Europe $^{a}$ & -166.4 & 60.3 & 134.2 & 194.5 & 336.3 & 433.9 & 427.6 & 471.6 & 450.3 \\
\hline EU-15 & -127.3 & 21.9 & 52.0 & 126.7 & 233.6 & 301.1 & 313.0 & 356.9 & 350.6 \\
\hline EU-13 & -120.9 & -41.8 & -49.9 & -48.7 & -29.8 & -0.5 & -2.8 & 3.0 & 9.1 \\
\hline $\begin{array}{l}\text { Economies in } \\
\text { transition }^{\text {b }}\end{array}$ & 90.3 & 35.4 & 62.5 & 98.8 & 59.1 & 11.6 & 50.9 & 48.6 & -4.5 \\
\hline South-Eastern Europe & -18.6 & -7.5 & -6.0 & -8.5 & -8.5 & -5.7 & -6.2 & -4.4 & -4.3 \\
\hline $\begin{array}{l}\text { Commonwealth of } \\
\text { Independent States }\end{array}$ & 111.6 & 44.1 & 69.7 & 109.2 & 69.4 & 18.2 & 58.8 & 54.7 & 1.7 \\
\hline Developing economies $^{\mathrm{d}}$ & 726.8 & 366.0 & 385.3 & 444.0 & 453.8 & 362.5 & 371.3 & 170.9 & 166.1 \\
\hline Net fuel exporters & 426.1 & 64.5 & 213.5 & 474.6 & 465.3 & 369.2 & 190.4 & -182.5 & -140.5 \\
\hline Net fuel importers & 300.7 & 301.5 & 171.8 & -30.5 & -11.4 & -6.7 & 180.9 & 353.4 & 306.6 \\
\hline $\begin{array}{l}\text { Latin America and the } \\
\text { Caribbean }\end{array}$ & -39.0 & -33.6 & -96.9 & -113.9 & -134.5 & $\begin{array}{l}-164.1 \\
\end{array}$ & -183.8 & -172.8 & -98.7 \\
\hline Net fuel exporters & 37.1 & -1.5 & 0.2 & 10.5 & -3.6 & -2.7 & -10.7 & -37.8 & -19.0 \\
\hline Net fuel importers & -1.9 & -35.1 & -96.7 & -103.4 & -138.1 & -166.7 & -194.5 & -210.6 & -117.7 \\
\hline Africa & 21.3 & -44.9 & -9.9 & -12.9 & -43.2 & -62.5 & -95.6 & -144.2 & -119.6 \\
\hline Net fuel exporters & 108.3 & 1.2 & 40.4 & 43.6 & 54.3 & 14.3 & -42.1 & -90.6 & -68.4 \\
\hline Net fuel importers & -87.0 & -46.1 & -50.3 & -56.5 & -97.6 & -76.8 & -53.5 & -53.6 & -51.2 \\
\hline Western Asia & 220.8 & 36.6 & 99.2 & 274.1 & 338.5 & 278.3 & 196.2 & -77.9 & -96.1 \\
\hline Net fuel exporters & 264.2 & 48.1 & 146.5 & 351.8 & 400.6 & 348.6 & 242.7 & -47.6 & -62.0 \\
\hline Net fuel importers & -43.4 & -11.5 & -47.3 & -77.7 & -62.1 & -70.3 & -46.5 & -30.3 & -34.0 \\
\hline East and South Asia & 523.9 & 407.8 & 392.9 & 296.7 & 293.2 & 310.8 & 454.5 & 565.9 & 480.5 \\
\hline Net fuel exporters & 16.6 & 16.6 & 26.4 & 68.6 & 13.9 & 8.9 & 0.4 & -6.5 & 8.9 \\
\hline Net fuel importers & 507.3 & 391.2 & 366.5 & 228.1 & 279.2 & 301.8 & 454.1 & 572.4 & 471.6 \\
\hline World residual $^{\mathrm{e}}$ & 51.4 & 145.3 & 266.2 & 323.7 & 345.7 & 390.8 & 421.0 & 273.8 & 259.4 \\
\hline
\end{tabular}

Source: International Monetary Fund (IMF), World Economic Outlook database, October 2017.

a Europe consists of the EU 15, the EU 13 and Iceland, Norway and Switzerland (Table A).

b Includes Georgia.

c Excludes Georgia, which left the Commonwealth of Independent States on 18 August 2009. 
d Libya has been excluded in the calculation due to unavailability of data.

e Statistical discrepancy.

Note: IMF-WEO has adopted the sixth edition of the Balance of Payments Manual (BPM6).

The balance of payment position of the world and countries are given in Table 2 presents that it is improving for the developing countries (-765.7 percent in 2008 and 97.8 percent in 2016), developing economies (-726.8 percent in 2008 and 166.1 percent in 2016) etc., and not favourable to United States (-681.4 percent in 2008 and -451.7 percent in 2016), south eastern Europe (-18.6 percent in 2008 and -4.3 percent in 2016) etc., as shown in chart 5.

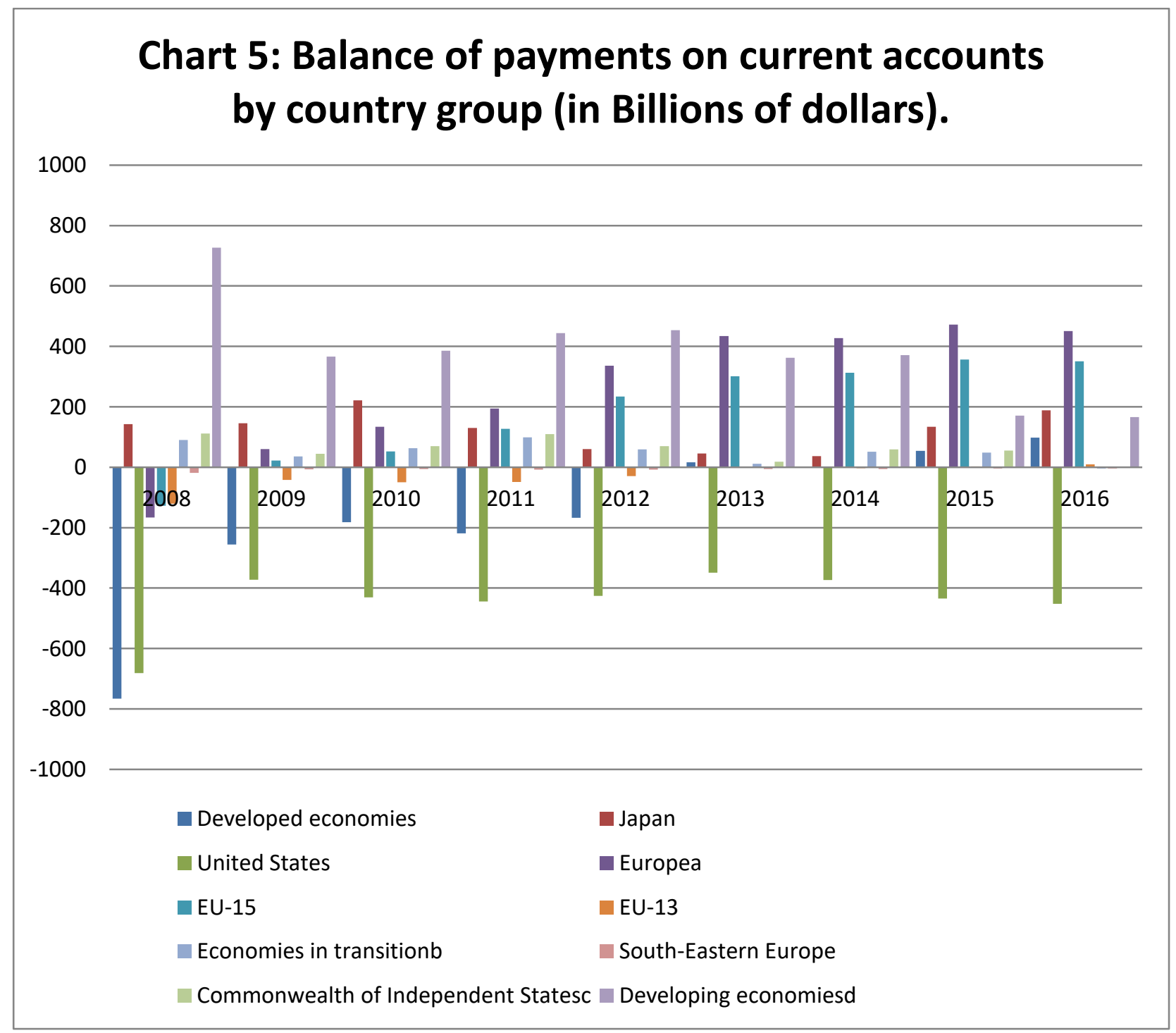

The above figures explain the international trade carried out by different countries and their performance index. The third factor for discussion is investments. Globally, investments has declined due to fragility of the global economies caused by weakness of aggregate demand, 
slow growth in some commodity export countries, policies on tax by countries, slump in MNEs etc. Countries like India with its new schemes like Make in India and renewed areas of identification attract more FDI. India had occupied $13^{\text {th }}$ position in $2013,9^{\text {th }}$ place in 2010 and today it is one of the top destination of FDI among the countries.

Inclusive growth is yet another challenge for global development as everybody should be given equal place in the orbit of economic growth. The very purpose of this initiative is to achieve equality of countries and people in the global development with equal status. This will make all the countries to grow simultaneously to avert unequal development in the future. India has implemented inclusive growth as a strategy of growth during the plan periods and it is continuing even after abandoning of the Planning Commission by the Government of India.

The factors like employment and the labour market are the channels through which globalization can influence the developing countries. Employment and labor earnings have been influenced by increased import penetration, export, sales, competition in services, foreign direct investment, exchange rate fluctuations and international capital movements etc. The "cheap" labor and the "race to the bottom" are the flip side of globalization. The new economic policies (NEP) of the countries have also impacted on labour and employment sector in the countries. When it comes to global labour market, it is influenced by quality of labour to cater the needs of the modern industries. It is estimated by 2020 about 500 million new jobs have to be created. The employers have reported that 38 percent of jobs could not be filled due to quality of labour in the international market.

The monetary policies of the country are another prime factor to be considered in the global development because the policy of one government will influence the other countries. The financial crisis in the countries directly affects global development position. Therefore, the financial sector should be strong and resilient to withstand and counter such crises. Otherwise weakness in the financial system will make it vulnerable due to internet connected global market. Some of the notable crises are: "Turkish economic crisis in 200-2001 and in 2018, Argentine economic crisis in 1999-2002, Icelandic financial crisis in 2008-2011, European sovereign debt crisis in 2010, Russian financial crisis in 2014, Greek government-debt crisis in 2010-2018 etc." Such crises that emanates from a country will not only affect that economy but also other economies of the world. The impact will be more severe if financial crisis occurs in the powerful economies of the world.

The next factor, gender issues deals with equality between men and women in terms of access to employment, decision making, health, education, political etc. However, globally gender gap is the major factor and it is more in the developing countries. It is out of the existing trend of gender inequalities and the treatment meted out to women in terms of demographic discrimination which is predominantly prevailing in developing nations. This necessitates sociological and political changes to promote the economic progress, particularly with reference to illiterate women. High maternal and infant mortality, women's health, and pre and postnatal 
care get lesser attention in the developing countries. The recent Global Gender Gap Report states that in another 118 years that is in 2133 the economic gap will be entirely wiped away from the world.

Food security is going to be a major challenge as the population statistics given in Chart 1 indicates that the world total population would reach 11.2 billion in 2100 . In order to feed the people during the period the countries have to produces 60 percent more commodities than what they produce now. The United Nations in its 17 Sustainable Development Goals (SDGs) for the year 2030 has set goals to end hunger, achieving improved nutrition and food security. Sustainable agriculture is also included in these Goals. Greenhouse gas emissions, water use and waste reduction are also being attended in the Goals.

Internet vis-à-vis information and communication technology is ruling the world. It is changing the way of life, work, production and consumption. The extensive reach of this technology has become more intensive in contributing to the growth of firms and also helps in business models. It is expected that by 2025 about 10 percent of the population will be using clothes related to internet with implantable mobile phones. Trillions of censors is expected to be connected in the internet. Worldwide 43 percent of the people are connected to the internet. The advancement in the information and communication technology has put India on the global map with a remarkable position. This industry is pegging its contribution at 9.3 per cent of the Gross Domestic Product of India (Ministry of Electronics and Information Technology, 2018) and its share in global market is 7 per cent. The mobile phone users in India was 524.9 million in 2013 and it is 813.2 million in 2019. No doubt these technologies helps in industrial and human development, but the certain harmful side also needs careful attention to mitigate its effects.

\section{CONCLUSION}

A healthy regional economic situation is imperative factors for achieving global development. The right type of policy measures and resource position of the countries of the world have brought remarkable changes in the economies of these countries. They have tide over many hurdles and their perceived efforts and dedicated labour have not only brought them in the limelight but also pushed them in the arena of growth. They could achieve such level through varies policies and efforts to accomplish declining inflation, improved financial stability, consolidation measures, reduced public expenditure, cut in fiscal deficits in the post-crisis period, lower public debt levels, increase in regional unemployment, better global liquidity, reduced risk aversion, portfolio capital flows, stronger external demand, increase in domestic demand, lesser corporate and household debt, recovery in commodity prices, good terms of trade and export earnings, more female labour participation, reduction in Current account deficits and improved BOP position etc. Armed conflict, terrorism, geopolitical tension and political instability are the serious factors that tremble world peace, global development and regional economic disparity. 


\section{REFERENCES:}

1. Arvind Virmani and Surabhi Mittal (2006): Domestic Market Integration, ICRIER Working Paper No. 183, July 2016.

2. Dandekar,V.M. (1996): Population, Poverty and Employment, in The Indian Economy Vol. II. Sage Publications, New Delhi.

3. Ministry of Electronics and Information Technology: http://meity.gov.in/content/factsheet-it-bpm-industry. Accessed on 14.10.2018.

4. Theodore W.Schultz, (1978): Distortion of Agricultural Incentives, Bloomington, Indiana University Press.

5. United Nations, (2018): "World Economic Situation 2018 and Prospects," published by the United Nations Department of Economic and Social Affairs (UN/DESA), the United Nations Conference on Trade and Development (UNCTAD) and the five United Nations regional commissions (Economic Commission for Africa (ECA), Economic Commission for Europe (ECE), Economic Commission for Latin America and the Caribbean (ECLAC), Economic and Social Commission for Asia and the Pacific (ESCAP) and Economic and Social Commission for Western Asia (ESCWA)). The United Nations World Tourism Organization (UNWTO) also contributed to the report, 2018, p.2. 